(науковий керівник - кандидат сільськогосподарських наук I. I. Гасанова)

ДУ Інститут сільського господарства степової зони

\title{
ПРОДУКТИВНІСТЬ ТА ЯКІСТЬ ЗЕРНА ПШЕНИЦ ОЗИМОЇ ЗАЛЕЖНО ВІД АЗОТНИХ ПІДЖИВЛЕНЬ ПІСЛЯ ЯЧМЕНЮ ЯРОГО
}

\section{Рецензент - доктор сільськогосподарських наук І. І. Ярчук}

Розглянуто урожайність та якість зерна (натура, вміст білка і клейковини, ВДК) нових сортів пшениці озимої після ячменю ярого. Виявлено, щуо більшу урожайність усіх сортів було отримано в сприятливі за зволоженням 2013 та 2014 рр., меншу - в посушливому 2012 рочі. Встановлено вплив азотних підживлень на формування показників урожайності та якості зерна пшениці озимої. Найбільше білка та клейковини в зерні відмічали у сорту Сонечко та у варіанті, в якому поєднували внесення аміачної селітри рано весною по таломерзлому трунту $i$ в кінці кущіння локально.

Ключові слова: пшеничя озима, сорт, аміачна селітра, КАС, карбамід, урожайність, натура зерна, білок, клейковина.

Постановка проблеми. На сьогоднішній день у Степу України значного поширення набувають високорентабельні культури, такі як ріпак, соняшник, зернові колосові. Тому сільськогосподарські виробники вимушені значні площі пшениці озимої розміщувати саме після таких попередників. Це, в свою чергу, призводить до недобору зерна, а також до погіршення його якості. Розробка ефективних прийомів поліпшення технологічних показників зерна після нетрадиційних для пшениці озимої попередників $є$ актуальними дослідженнями, адже в останні роки спостерігається зменшення частки продовольчого зерна поліпшеної якості, найбільш придатного для борошномельної та хлібопекарської промисловості. Серед таких прийомів одне 3 перших місць займає мінеральне удобрення посівів пшениці i, зокрема застосування азотних підживлень.

Аналіз основних досліджень і публікацій, у яких започатковано розв'язання проблеми. Відомо, що урожайність та якість зерна пшениці озимої визначається багатьма чинниками: кліматичними, грунтовими, а також сортом, попередником, рівнем мінерального живлення. Питання взаємозв'язку урожайності, якості зерна та рівня мінерального живлення глибоко вивчали у 60-80 pp. минулого століття $[1,7]$. Однак сучасні висо- ко інтенсивні сорти пшениці озимої суттєво відрізняються від попередніх агротехнікою рослини, деякими біохімічними показниками та потенційною продуктивністю [6].

Працями багатьох вчених встановлено, що в поліпшенні якості зерна провідну роль відіграють азотні добрива $[4,2]$. Науковий досвід та виробнича практика [9] переконливо показали, що дефіцит в грунті мінеральних форм азоту призводить до зниження кількості білка та клейковини в зерні пшениці. Особливе місце серед азотних підживлень посівів пшениці озимої займають позакореневі, особливо тоді, коли верхній шар грунту має низьку вологість і мінеральні добрива недостатньо розчиняються і засвоюються рослинами. Традиційно позакореневі підживлення проводять розчином карбаміду. Карбамід легко розчиняється у воді, він, як правило, не обпікає рослини. Для запобігання появі некрозів вегетативної маси рослин i, особливо, прапорцевого листка, концентрація карбаміду в робочому розчині має становити $10-13 \%$. Дослідження показують, що зі збільшенням дози карбаміду підвищується вміст білка і клейковини в зерні. Кращою дозою в усі строки підживлення є 30-45 кг/га діючої речовини карбаміду [8].

Перспективними є розчини аміачної селітри й карбаміду (КАС), які містять 28-32 \% азоту. Собівартість цього добрива нижча, ніж твердих азотних добрив, його можна застосовувати восени під основний обробіток грунту, весною - під передпосівний обробіток та в період вегетації сільськогосподарських культур для кореневих $\mathrm{i}$ позакореневих підживлень.

Під час внесення КАС необхідно використовувати розпилювачі для крупно крапельного внесення рідких добрив.

Кращий час для позакореневого підживлення розчинами КАС - ранкові (в разі відсутності роси) та вечірні години. Не слід підживлювати рослини розчинами КАС за температури вище $20{ }^{\circ} \mathrm{C}$, низької відносної вологості повітря (менше $56 \%$ ), в сонячний день, так як в цих випадках можливі опіки листкової поверхні рослин. Най- 


\section{СТОРІНКА МОЛОДОГО ВЧЕНОГО}

більш ефективні обробки КАС у похмуру погоду. Строки внесення добрива на пшеницю озиму часто збігаються зі строками обробки посівів гербіцидами, фунгіцидами й ретардантами. Тому винесення КАС можна легко комбінувати з засобами захисту рослин від бур'янів і хвороб [5].

Метою наших досліджень було визначити оптимальні варіанти азотних підживлень для формування продуктивності та якості зерна пшениці озимої після ячменю ярого в умовах північного Степу.

Завдання досліджень: охарактеризувати вплив погодних умов на урожайність та якість зерна нових сортів пшениці озимої після ячменю ярого; виявити вплив підживлень посівів різними азотними добривами на показники урожайності та якості зерна.

Методика проведення досліджень. Дослідження проводили в Дослідному господарстві «Дніпро» Інституту сільського господарства степової зони НАAН (Дніпропетровська область) протягом 2011-2014 років. Грунтовий покрив ділянок - чорнозем звичайний малогумусний важкосуглинковий із вмістом гумусу в орному шарі $3,2 \%$. Клімат зони - помірноконтинентальний 3 недостатнім та нестійким зволоженням.

Матеріалом для досліджень були сорти пшениці м'якої озимої різних оригінаторів: Литанівка, Заможність, Антонівка, Розкішна, Сонечко. Під час проведення польових дослідів користувалися загальноприйнятою методикою Б. О. Доспєхова [3].

Попередник - ячмінь ярий. Фонове добриво $\left(\mathrm{N}_{60} \mathrm{P}_{60} \mathrm{~K}_{30}\right)$ вносили під передпосівну культивацію розкидачем 1-РМГ-4. Для підживлень використовували наступні азотні добрива: аміачна селітра, карбамід, КАС-32. Підживлення аміачною селітрою проводили ранньою весною (по таломерзлому грунту) та в кінці кущіння рослин пшениці озимої (локально); позакореневі підживлення карбамідом - в колосіння; внесення КАС шляхом обприскування по вегетуючих рослинах в кінці кущіння. Насіння пшениці висівали навісною сівалкою СН-16 з шириною міжрядь $15 \mathrm{~cm}$. Облікова площа ділянки - $35 \mathrm{~m}^{2}$, повторність триразова. У лабораторних умовах визначали натуру зерна, вміст білка та клейовини в зерні, показники приладу ВДК. Водночас користувалися методами, передбаченими діючими ДСТУ та загальноприйнятими методиками.

Результати досліджень. Результати досліджень, проведених упродовж 2011-2014 рр., свідчать, що урожайність та якість зерна сортів пшениці озимої суттєво варіювали по роках, що $€$ наслідком коливань погодних умов у роки експерименту. В умовах дефіциту вологи восени 2011 р. рослини пшениці озимої ввійшли у зиму слабо розкущеними, ослабленими та нерівномірно розвинутими. Недобір опадів спостерігали і в період весняної вегетації пшениці 2012 року. Вегетаційний період 2012/13 р. був у цілому сприятливим, а протягом весняної вегетації в 2014 р. зафіксовано найбільше опадів 3-поміж років досліджень, що значно покращило стан рослин пшениці озимої після непарових попередників.

Погодні умови, які склалися в роки досліджень, мали значний вплив і на формування продуктивності рослин пшениці озимої, і на якість іiі зерна. Так, урожайність у 2012 р. була значно нижчою, ніж в 2013 та 2014 рр., і змінювалася залежно від сортів від 1,94 до 2,64 т/га. В 2013 р. такі показники коливалися від 4,18 до 5,07 , а в 2014 р. - від 4,83 до 5,57 т/га. В посушливому 2012 р. більш врожайними були сорти Сонечко (Інститут фізіології рослин і генетики) та Розкішна (Інститут рослинництва ім. Юр'єва), які відрізнялися вищим стеблостоєм порівняно 3 сортами Селекційно-генетичного інституту. В сприятливі за зволоженням 2013 та 2014 рр. більшу кількість продуктивних стебел на одиницю площі формували сорти Литанівка та Розкішна. Однак урожайність залежить не тільки від цього показника, але й від кількості зерен у колосі та маси 1000 зерен, які визначають масу зерна 3 колоса. В 2013 р. вищу врожайність відмічали у сортів Литанівка та Заможність, а в 2014 - у сорту Розкішна (табл. 1).

Відомо, що вміст білка та клейковини в зерні залежить від погодних умов упродовж вегетаційного періоду.

Низька вологість повітря, висока температура i дефіцит вологи в грунті протягом вегетації сприяють підвищенню вмісту білка та клейковини в зерні порівняно з більш вологим періодом. До того ж існує зворотній зв'язок між урожайністю та білковістю зерна.

Так, у посушливому 2012 р. вміст білка в зерні сортів змінювався від 13,9 до 15,6 \%, клейковини - від 32,3 до 35,5 \% за показників ВДК 85-92 од. пр. У 2013 та 2014 рр. кількість білка в зерні становила від 11,0 до 13,4 \%, а клейковини - від 19,0 до 32,7 \% за показників ВДК 48-84 од. пр. Слід відмітити, що в усі роки досліджень найбільше білка та клейковини в зерні було у сорту Сонечко. Кращу натуру зерна переважно спостерігали у сортів Литанівка та Розкішна. В 2012 р. було отримано, як правило, зерно 1-го класу якості, а в 2013 та 2014 pp. - 3-го. 
СТОРІНКА МОЛОДОГО ВЧЕНОГО

\section{1. Показники якості зерна нових сортів пшениці озимої після ячменю ярого (2012-2014 рр.)}

\begin{tabular}{|c|c|c|c|c|c|c|}
\hline \multirow{2}{*}{ Сорт } & \multirow{2}{*}{$\begin{array}{c}\text { Урожай- } \\
\text { ність, } \\
\text { т/га }\end{array}$} & \multirow{2}{*}{$\begin{array}{c}\text { Натура зерна, } \\
\text { Г/л }\end{array}$} & \multicolumn{2}{|c|}{ Вміст у зерні, \% } & \multirow{2}{*}{$\begin{array}{l}\text { ВДК, } \\
\text { од. пр. }\end{array}$} & \multirow{2}{*}{$\begin{array}{c}\text { Клас зерна } \\
\text { (за ДСТУ } \\
\text { 3768:2010) }\end{array}$} \\
\hline & & & білка & клейковини & & \\
\hline \multicolumn{7}{|c|}{2012 p. } \\
\hline Литанівка & 1,94 & 769 & 14,5 & 35,3 & 90 & 1 \\
\hline Заможність & 2,43 & 760 & 15,3 & 33,9 & 85 & 1 \\
\hline Антонівка & 2,21 & 767 & 15,2 & 35,2 & 86 & 1 \\
\hline Сонечко & 2,64 & 770 & 15,6 & 35,5 & 92 & 1 \\
\hline Розкішна & 2,60 & 779 & 13,9 & 32,3 & 86 & 2 \\
\hline У середньому & 2,36 & 769 & 14,9 & 34,4 & 88 & 1 \\
\hline $\mathrm{HIP}_{05}$ & 0,11 & 6 & 0,6 & 1,5 & 5 & - \\
\hline \multicolumn{7}{|c|}{2013 p. } \\
\hline Литанівка & 4,93 & 780 & 11,8 & 21,0 & 61 & 3 \\
\hline Заможність & 5,07 & 771 & 12,2 & 22,5 & 64 & 3 \\
\hline Антонівка & 4,18 & 764 & 11,6 & 21,5 & 65 & 3 \\
\hline Сонечко & 4,24 & 768 & 12,4 & 23,0 & 63 & 3 \\
\hline Розкішна & 4,61 & 776 & 11,0 & 19,0 & 48 & 3 \\
\hline У середньому & 4,61 & 772 & 11,8 & 21,4 & 60 & 3 \\
\hline $\mathrm{HIP}_{05}$ & 0,18 & 4 & 0,4 & 1,0 & 5 & - \\
\hline \multicolumn{7}{|c|}{2014 p. } \\
\hline Литанівка & 5,35 & 782 & 11,6 & 26,4 & 69 & 3 \\
\hline Заможність & 5,32 & 772 & 11,6 & 26,1 & 63 & 3 \\
\hline Антонівка & 5,28 & 770 & 12,1 & 25,9 & 63 & 3 \\
\hline Сонечко & 4,36 & 764 & 13,4 & 32,7 & 84 & 2 \\
\hline Розкішна & 5,66 & 784 & 12,1 & 29,0 & 73 & 3 \\
\hline У середньому & 5,19 & 774 & 12,2 & 28,0 & 70 & 3 \\
\hline $\mathrm{HIP}_{05}$ & 0,20 & 6 & 0,5 & 1,2 & 6 & - \\
\hline
\end{tabular}

2. Вплив азотних підживлень на урожайність і якість зерна пшениці озимої після ячменю ярого (у середньому за 2012-2014 рр.)

\begin{tabular}{|c|c|c|c|c|c|c|}
\hline \multirow{2}{*}{ Варіант удобрення } & \multirow{2}{*}{$\begin{array}{l}\text { Урожай- } \\
\text { ність, т/га }\end{array}$} & \multirow{2}{*}{$\begin{array}{c}\text { Натура } \\
\text { зерна, } \\
\text { г/л }\end{array}$} & \multicolumn{2}{|c|}{ Вміст у зерні, \% } & \multirow{2}{*}{$\begin{array}{l}\text { ВДК, } \\
\text { од. пр. }\end{array}$} & \multirow{2}{*}{$\begin{array}{c}\text { Клас зерна } \\
\text { (за ДСТУ } \\
\text { 3768:2010) }\end{array}$} \\
\hline & & & білка & клейковини & & \\
\hline Без підживлення (контроль) & 3,85 & 767 & 12,3 & 25,7 & 71 & 3 \\
\hline $\begin{array}{l}\mathrm{N}_{30} \text { в кінці кущіння } \\
\text { аміачна селітра }\end{array}$ & 4,03 & 771 & 13,0 & 28,0 & 71 & 2 \\
\hline $\mathrm{N}_{30}$ в кінці кущіння КАС & 3,97 & 778 & 12,6 & 26,4 & 71 & 2 \\
\hline $\begin{array}{c}\mathrm{N}_{30} \text { ранньою весною }+\mathrm{N}_{30} \mathrm{~B} \\
\text { кінці кущіння аміачна селітра }\end{array}$ & 4,18 & 769 & 13,5 & 29,5 & 73 & 2 \\
\hline $\begin{array}{l}\mathrm{N}_{60} \text { В кінці кущіння } \\
\text { аміачна селітра }\end{array}$ & 4,19 & 774 & 12,9 & 28,1 & 74 & 2 \\
\hline $\begin{array}{c}\mathrm{N}_{30} \text { в кінці кущіння аміачна } \\
\text { селітра }+\mathrm{N}_{30} \text { в колосіння } \\
\text { карбамід }\end{array}$ & 3,98 & 775 & 13,2 & 29,1 & 75 & 2 \\
\hline $\mathrm{HIP}_{0,5}$ & 0,16 & 7 & 0,6 & 1,5 & 7 & - \\
\hline
\end{tabular}




\section{СТОРІНКА МОЛОДОГО ВЧЕНОГО}

Вплив рівня мінерального живлення, головним чином азотного, на продуктивність і якість зерна пшениці озимої є надзвичайно важливим фактором технології їі вирощування після непарових попередників. Результати досліджень, проведених упродовж 2012-2014 рр., свідчать, що урожайність пшениці озимої після ячменю ярого по варіантах, що вивчали, становила від 3,85 до 4,19 т/га. Найефективнішими виявилися наступні варіанти: проведення весняного азотного підживлення аміачною селітрою нормою $\mathrm{N}_{60}$ в кінці кущіння (4,19 т/га); двохразове внесення аміачної селітри $-\mathrm{N}_{30}$ ранньою весною $+\mathrm{N}_{30}$ в кінці кущіння (4,18 т/га). Найменшу урожайність було сформовано на контролі - 3,85 т/га і під час внесення КАС у кінці кущіння - 3,97 т/га (табл. 2).

Найбільше білка та клейковини в зерні було отримано за двохразового внесення аміачної селітри $\left(\mathrm{N}_{30}\right.$ ранньою весною $+\mathrm{N}_{30}$ в кінці кущіння). Ці значення відповідно становили 13,5 та 29,5 \%. Натура зерна по варіантах досліду змінювалася від 767 до 778 г/л, а показники ВДК від 71 до 75 од. пр. Якість зерна (згідно з ДСТУ

\section{БІБЛІОГРАФІЯ}

1. Андрианова Ю. Е. Хлорофилл и продуктивность растений / Ю. Е. Андрианова, И. А. Тарчевский. - М. : Наука, 2000.- 135 с.

2. Господаренко Г. М. Основи інтегрованого застосування добрив / Г. М. Господаренко. - М. : ЗАТ НЧЛАВА, 2002. $-344 \mathrm{c}$.

3. Доспехов Б. А. Методика полевого опыта / Б. А. Доспехов. - М. : Агропромиздат, 1985. $351 \mathrm{c}$.

4. Жемела Г. П. Добрива, урожай і якість зерна / Григорій Пимонович Жемела. - К. : Урожай, 1991. - 136 с.

5. Масляний О. Усі тонкощі про КАС / О. Масляний // Пропозиція. - 2012. - №2 . - С. 62-64.

6. Моргун B. В. Фізіологічні основи формування високої продуктивності зернових злаків / В. В. Моргун, В. В. Швартау, Д. А. Кірізій // Фізіологія рослин: проблеми та перспективи розвит-
3768:2010) відповідала 2-му класу, крім у варіанті, де підживлення не проводили (3-й клас).

\section{Висновки:}

1. Найбільша продуктивність сортів пшениці озимої після ячменю ярого формувалася у вологому 2014 р. і відповідала в середньому по сортах 5,19 т/га. Максимальну урожайність у цьому році відмічали у сорту Розкішна (5,66 т/га). Якість зерна в посушливому 2012 р. була переважно 1-го класу, а в сприятливих за зволоженням 2013 та 2014 роках - 3-го. В усі роки досліджень найбільше білка та клейковини в зерні спостерігали у сорту Сонечко.

2. Серед варіантів азотних підживлень найбільша урожайність пшениці озимої в середньому за 2012-2014 pр. була отримана за внесення в кінці кущіння аміачної селітри нормою $\mathrm{N}_{60}$ та за двохразового внесення аміачної селітри $\left(\mathrm{N}_{30}\right.$ ранньою весною $+\mathrm{N}_{30}$ в кінці кущіння). Найкраща якість зерна (13,5 \% білка та 29,5 \% клейковини) формувалася за двохразового внесення аміачної селітри $\left(\mathrm{N}_{30}\right)$ - ранньою весною та в кінці кущіння.

ку : зб. наук. пр. у 2-х т. - К. : Логос, 2009. - Т.1. С. 11-42.

7. Рекомендації по виробництву високоякісного зерна озимих сортів пшениці і тритикале в північному Степу України / [Черенков А. В., Гасанова I. І., Солодушко М. М., Конопльова С. Л. та ін.] // Рекомендації. - Дніпропетровськ, 2011. $22 \mathrm{c}$.

9. Хохлов О. М. Співвідношення вмісту білка та сирої клейковини в зерні сортів м'якої пшениці різної хлібопекарської якості / О. М. Хохлов, Н. А. Литвиненко // Вісник аграрної науки. 1999. - Вип. 1. - С. 22-27.

10. Richards R. A. Selectable trains to increase crop photosynthesis and yield of grain crops / R. A. Richards // Journal of Experimental Botany. - 2000. №51. - P. 447-458. 